\title{
PEMETAAN SUMBERDAYA APARATUR DESA DI PROVINSI KALIMANTAN TIMUR
}

\section{(VILLAGE APARATURE RESOURCES MAPPING IN EAST KALIMANTAN PROVINCE)}

\author{
Nofiarsyah \\ Badan Penelitian dan Pengembangan Daerah Provinsi Kalimantan Timur \\ Jl. MT. Haryono No. 126 Samarinda \\ Email: nofiarsyah32@gmail.com
}

Diterima: 29 Oktober 2019; Direvisi: 30 Desember 2019; Disetujui: 31 Desember 2019

\begin{abstract}
ABSTRAK
Lahirnya UU 6/2014 tentang Desa, membutuhkan kesiapan pelaksanaannya terutama kesiapan sumberdaya aparatur pemerintah desa (SDAP). Tujuan dari penelitian ini adalah pemetaan kapasitas dan mengembangkan strategi peningkatan kapasitas SDAP desa. Penelitian menggunakan pendekatan kualitatif menggunakan data primer (wawancara dan observasi dokumen serta artefak) serta data sekunder dari instansi terkait. Hasil penelitian menemukan bahwa kapasitas sumberdaya aparatur desa di Kalimantan Timur masih belum optimal baik ditinjau dalam aspek Perencanaan dan Penganggaran Desa, Keuangan Desa, Penyusunan Kebijakan Desa, dan Manajemen Pelayanan Desa. Berbagai program peningkatan kapasitas telah dilakukan baik oleh Pemerintah Provinsi, Pemerintah Kabupaten maupun inisiatif Pemerintah Desa. Namun berbagai program peningkatan kapasitas belum terintegrasi antar instansi, serta lebih banyak pada aspek teknis. Di sisi lain, pengelolaan sumberdaya desa tidak hanya membutuhkan kapasitas teknis, namun kapasitas manajemen, kewirausahaan dan kapasitas berfikir konseptual. Sumberdaya aparatur di wilayah perdesaan, sebagian besar berpendidikan SMA ke bawah secara umum mempunyai potensi kearifan lokal, namun terbatas untuk kapasitas manajerial dan kapasitas berfikir konseptual. Penelitian ini merekomendasikan strategi yang dapat diterapkan untuk penguatan kapasitas sumberdaya aparatur desa desa selain melalui sosialisasi, pelatihan, bimbingan teknis, konsultasi yang selama ini dilakukan yaitu melalui penguatan kapasitas manajemen dan kewirausahaan. Kedua, melalui pengembangan modul-modul yang memudahkan SDAP desa dalam pengelolaan sumberdaya desa.
\end{abstract}

Kata kunci: Desa, Kapasitas, Sumberdaya Aparatur

\begin{abstract}
The issuance of Law 6/2014 concerning Village Government requires readiness for its implementation, especially the readiness of village apparatus resources. The purpose of this activity is to map capacity and develop strategies to increase village apparatus resources capacity. The study uses a qualitative approach using primary data (interviews and observation of documents and artifacts) as well as secondary data from related institutions. The results of the study found that the capacity of village apparatus resources in East Kalimantan was still not optimal both in terms of Village Planning \& Budgeting, Village Finance, Village Policy Formulation, and Village Service Management. Various capacity building programs have been carried out both by the Provincial Government, District Government and the Village Government initiative. However, various capacity building programs have not been integrated between agencies, and there are more technical aspects. On the other hand, management of village resources on the other hand requires not only technical capacity, but management capacity, entrepreneurship and capacity for conceptual thinking. Apparatus Resources in rural areas, most of them with high school education and below generally have local wisdom potential, but are limited to managerial capacity and capacity for conceptual thinking. This article recommends strategies that can be applied to strengthen the capacity of the village apparatus resources in addition to through socialization, training, technical guidance, consultation that has been carried out so far
\end{abstract}


Pemetaan Sumberdaya Aparatur Desa di Provinsi Kalimantan Timur

Nofiarsyah

through strengthening management and entrepreneurial capacity. Second, through the development of modules that facilitate village human resources development in managing village resources.

Keywords: Apparature Resources, Capacity, Village

\section{PENDAHULUAN}

Pembangunan wilayah perdesaan mempunyai sejumlah tantangan di era pengetahuan, peningkatan konektivitas global serta peningkatan kesadaran pembangunan berkelanjutan pada abad ke-21 (Horner 2019; Guinjoan et al., 2016). Pembangunan wilayah perdesaan telah mengalami perubahan paradigma pada abad ke-21 (OECD, 2016), yaitu tidak hanya fokus pada sektor pertanian namun multi sektor baik industri dan jasa, pertanian dari rantai hulu-hilir, pertanian terpadu (produksi, kesehatan, lingkungan, energi). Pembangunan perdesaan tidak hanya fokus pembangunan wilayah pedesaan namun keterkaitan antara pedesaan dan perkotaan ( ruralurban linkage) serta lebih banyak pihak yang terlibat, baik pemerintah, swasta, lembaga donor, baik tingkat lokal, regional dan global (OECD, 2016).

Perubahan paradigma dalam pembangunan wilayah perdesaan memberikan peluang dan tantangan dalam pengembangan sumberdaya manusia di wilayah perdesaan (Vincent \& Stephen, 2015; Davies, 2009). Kapasitas sumberdaya Aparatur Desa diperlukan (Vincent \& Stephen, 2015; Ahmed \& Hanson, 2011) sebagai agen perubahan (Steiner \& Farmer, 2017; Denhardt \& Denhardt, 2004) untuk menangkap peluang dari perubahan lingkungan (Ahmed \& Hanson, 2011). Sumberdaya Aparatur Desa memerlukan kapasitas kearifan lokal (Sidik, 2015) sekaligus agen pembelajar dan katalis terhadap perubahan lingkungan yang semakin kompleks dan dinamis. Banyak potensi-potensi ekonomi, sosial, lingkungan yang dapat dikembangkan di wilayah perdesaan, seperti: pengembangan pertanian terpadu (menggabungkan aktivitas pertanianpeternakan-energi) (Pujiyatno \& Miftahuddin, 2017; Agus et al., 2015), Smart Village (Herdiana, 2019; Suranto, 2018), desa mandiri energi (Taufiq et al., 2016; Taufiq \& Purwoko, 2013), desa wisata (Sidik, 2015), dan pengelolaan sumberdaya air, energi berbasis masyarakat (Pusut et al., 2017). Berbagai potensi tersebut memerlukan kapasitas pengelolaan yang tidak hanya sebatas kapasitas teknis, namun juga kapasitas manajerial dan kewirausahaan (Krakowiak-Bal et al., 2017) serta kapasitas berfikir konseptual dalam perencanaan, penganggaran, manajemen keuangan dan sumberdaya (aset) desa, perumusan kebijakan, implementasi program kebijakan, monitoring dan evaluasi (Krakowiak-Bal et al., 2017).

Perubahan lingkungan dan regulasi (seperti implementasi UU 6/2014) memerlukan dukungan kapasitas sumberdaya aparatur desa. Namun demikian, studi di beberapa wilayah menunjukkan kapasitas sumberdaya aparatur desa masih rendah. Banyak pemerintah desa memiliki persoalan minimnya kapasitas sumber daya manusia aparatur desa, kuantitas perangkat desa sangat kurang, dan perangkat desa belum memahami tupoksi masing-masing (Sulismadi, et al., 2017; Arsjad, 2018). Asrori (2014) juga menemukan bahwa tingkat pemahaman perangkat desa dalam memahami majemen sumberdaya manusia maupun kemampuan teknis perangkat desa masih kurang. Ketua dan Anggota BPD juga belum dapat menjalankan fungsinya secara optimal (Romli $\&$ Nurlia, 2017). Beberapa studi lainnya menemukan bahwa efektivitas dan kinerja pembangunan desa ditentukan kapasitas sumberdaya manusia termasuk sumberdaya aparatur desa (Hendri et al., 2016; Wiguna et al., 2017; Ardani, 2015), kepemimpinan (Eka \& Ismiyati, 2015), sarana prasarana (Hendri et al., 2016; Wiguna et al., 2017), keuangan (Wiguna et al., 2017), pendidikan dan pelatihan, serta peran pendamping desa (Wiguna et al., 2017). Lemahnya kapasitas sumberdaya aparatur desa berdampak pada kegagalan implementasi undang-undang desa sehingga bermuara pada buruknya pembangunan desa (Hendri et al., 2016; Wiguna et al., 2017; Ardani, 2015).

Kapasitas sumberdaya aparatur diantaranya diperoleh dari rekrutmen dan pengembangan. Pengembangan kapasitas sebagai bagian dari pemberdayaan (Steiner \& Farmer, 2017) berkaitan dengan penguatan prinsip-prinsip inklusivitas, transparansi, akuntabilitas dan demokrasi (Boley 
dan McGehee, 2014). Pengembangan kapasitas sangat penting untuk membimbing agar masyakarat desa terbuka terhadap perubahan dan termotivasi untuk mencapai tingkat potensi maksimal dalam pengembangan komunitas (Steiner \& Farmer, 2017). Langkah awal pengembangan kapasitas sumberdaya aparatur desa adalah melalui pemetaan kapasitas yang telah tersedia.

Pemetaan bermanfaat untuk perencanaan pengembangan sumberdaya aparatur di tingkat desa dalam mendukung kegiatan pembangunan perdesaan. Dalam UU 6/2014 tentang Desa disebutkan bahwa perangkat desa diangkat oleh kepala desa dari penduduk desa. Namun demikian, kepala desa yang terpilih dalam proses pemilihan kepala desa (pemilu kepala desa atau yang lebih dikenal dengan Pilkades) belum tentu memiliki kompetensi yang diharapkan. Demikian juga kualitas pemilihan dan pengangkatan perangkat desa (kecuali Sekretaris Desa) belum tentu sepenuhnya didasarkan pada pertimbangan kompetensi. Hal tersebut menjadikan motivasi untuk melakukan kegiatan Pemetaan Sumberdaya Aparatur Desa di Provinsi Kalimantan Timur.

\section{METODE}

Penelitian pemetaan sumberdaya aparatur desa dilakukan di Provinsi Kalimantan Timur dilaksanakan pada bulan Juli-Agustus 2019. Lingkup pemetaan meliputi kondisi eksisting sumberdaya aparatur desa meliputi jumlah sumberdaya aparatur dan profil sumberdaya aparatur desa berdasarkan data pemetaan Potensi Desa (BPS, 2014, 2018), dan kapasitas sumberdaya aparatur desa secara kualitatif berdasarkan indikator Bappenas (2016) yang fokus pada aspek kapasitas: perencanaan dan penganggaran, manajemen aset dan keuangan desa, kebijakan dan kemampuan mengambil keputusan serta manajemen pelayanan desa.

Kapasitas perencanaan dan penganggaran adalah kemampuan/kompetensi aparatur desa dalam hal penyusunan Rencana Pembangunan Jangka Menengah Desa (RPJM Desa) dan Rencana Kerja Pembangunan Desa (RKP Desa). Kapasitas manajemen aset dan keuangan desa yaitu kapasitas aparatur desa dalam aspek administrasi dan operasional, manajemen keuangan dan investasi. Kapasitas kebijakan desa diartikan sebagai kapasitas dalam kelembagaan dalam penyusunan kebijakan desa. Kapasitas manajemen pelayanan desa adalah kapasitas aparatur desa dalam bidang pelayanan kepada masyarakat.

Penelitian menggunakan data wawanvara, observasi dokumen dan artefak. Wawancara dilakukan dengan kepala desa atau staf (aparat) desa yang mewakilinya pada desa di Kalimantan Timur. pendamping desa, staf Dinas Pemberdayaan Masyarakat dan Pemerintahan Desa (PMPD) Provinsi dan Kabupaten/Kota di Kalimantan Timur. Observasi dilakukan terhadap dokumen perencanaan desa seperti: RPJM Desa (lima tahunan), dokumen RKP Desa (tahunan), APBDes dan artefak seperti: papan informasi, poster publikasi pembangunan desa. Studi dokumen juga diperoleh dari Buku Statistik Potensi Desa Kalimantan Timur Tahun 2014 dan 2018 yang diterbitkan oleh BPS Kalimantan Timur dan Dokumen pendukung lainnya. Pemeriksaaan keabsahan data melalui teknik trianggulasi sumber dan metode. Analisis dilakukan dengan pendekatan kualitatif berdasarkan data kuantitatif dan data kualitatif.

\section{HASIL DAN PEMBAHASAN}

\section{Profil Sumberdaya Aparatur Desa}

Provinsi Kalimantan Timur terdiri dari 7 kabupaten, 3 kota, 103 kecamatan, 197 kelurahan dan 841 desa. Pemerintah Desa adalah kepala desa atau yang disebut dengan nama lain dibantu perangkat desa sebagai unsur penyelenggara pemerintahan desa. Perangkat desa terdiri dari sekretariat desa, pelaksana kewilayahan, dan pelaksana teknis (UU No. 6 Tahun 2014 tentang Desa).

Kepala Desa/Lurah adalah pejabat pemerintah desa yang mempunyai wewenang, tugas, dan kewajiban untuk menyelenggarakan rumah tangga desanya dan melaksanakan tugas dari Pemerintah dan Pemerintah Daerah. Sekretaris Desa/Kelurahan berkedudukan sebagai unsur 
pimpinan Sekretariat Desa. Sekretaris desa bertugas membantu kepala desa dalam bidang administrasi pemerintahan. Sekretariat Desa paling banyak terdiri atas 3 (tiga) urusan yaitu urusan tata usaha dan umum, urusan keuangan, dan urusan perencanaan, dan paling sedikit 2 (dua) urusan yaitu urusan umum dan perencanaan, dan urusan keuangan. Pelaksana Kewilayahan merupakan unsur pembantu kepala desa sebagai satuan tugas kewilayahan. Pelaksana Teknis merupakan unsur pembantu kepala desa sebagai pelaksana tugas operasional. Pelaksana teknis paling banyak terdiri atas tiga seksi yaitu seksi pemerintahan, seksi kesejahteraan dan seksi pelayanan, paling sedikit dua seksi yaitu seksi pemerintahan, serta seksi kesejahteraan dan pelayanan.

Tabel 1. Ketersediaan Sumberdaya Aparatur Desa di Kalimantan Timur

\begin{tabular}{|c|c|c|c|c|c|c|c|c|c|}
\hline \multirow[t]{2}{*}{ Kabupaten/Kota } & \multirow{2}{*}{$\begin{array}{c}\text { Desa + } \\
\text { Kelurah- } \\
\text { an } \\
\text { Jumlah }\end{array}$} & \multicolumn{2}{|c|}{ Kepala Desa + Lurah } & \multicolumn{2}{|c|}{$\begin{array}{c}\text { Sekretaris } \\
\text { Desa/Sekretaris } \\
\text { Kelurahan }\end{array}$} & \multicolumn{2}{|c|}{$\begin{array}{c}\text { Pelaksana } \\
\text { Kewilayahan }\end{array}$} & \multicolumn{2}{|c|}{ Pelaksana Teknis } \\
\hline & & Jumlah & Persen & Jumlah & Persen & Jumlah & Persen & Jumlah & Persen \\
\hline Paser & 144 & 135 & 93.75 & 86 & 59.72 & 144 & 100.00 & 143 & 99.31 \\
\hline Kutai Barat & 194 & 194 & 100.00 & 192 & 98.97 & 190 & 97.94 & 87 & 44.85 \\
\hline Kutai Kartanegara & 237 & 220 & 92.83 & 225 & 94.94 & 237 & 100.00 & 232 & 97.89 \\
\hline Kutai Timur & 141 & 135 & 95.74 & 141 & 100.00 & 141 & 100.00 & 139 & 98.58 \\
\hline Berau & 110 & 102 & 92.73 & 94 & 85.45 & 109 & 99.09 & 109 & 99.09 \\
\hline Penajam Paser Utara & 54 & 50 & 92.59 & 43 & 79.63 & 54 & 100.00 & 54 & 100.00 \\
\hline Mahakam Hulu & 50 & 42 & 84.00 & 50 & 100.00 & 50 & 100.00 & 39 & 78.00 \\
\hline Kota Balikpapan & 34 & 34 & 100.00 & 34 & 100.00 & 34 & 100.00 & 34 & 100.00 \\
\hline Kota Samarinda & 59 & 58 & 98.31 & 57 & 96.61 & 59 & 100.00 & 59 & 100.00 \\
\hline Kota Bontang & 15 & 15 & 100.00 & 15 & 100.00 & 15 & 100.00 & 15 & 100.00 \\
\hline Kalimantan Timur & 1038 & 985 & 94.89 & 937 & 90.27 & 1033 & 99.52 & 911 & 87.76 \\
\hline
\end{tabular}

Sumber: diolah dari data Statistik Potensi Desa Kalimantan Timur (2018)

Berdasarkan Tabel 1, sebagian besar desa dan kelurahan di Kalimantan Timur telah mempunyai Kepala Desa/Lurah (94,89\%), Sekretaris Desa/Sekretaris Kelurahan(90,27\%), Pelaksana Kewilayahan $(99,52 \%)$ dan Pelaksana Teknis $(87,76 \%)$, Sebagian kecil $(5,11 \%)$ desa dan kelurahan di Kalimantan Timur yang belum mempunyai kepala desa disebabkan oleh masa jabatan kepala desa sebelumnya yang telah habis dan belum dilakukkannya pemilihan kepala desa yang baru. Dari sebanyak 1038 desa dan kelurahan di Kalimantan Timur, sebanyak 101 desa $(9,73 \%)$ belum mempunyai sekretaris desa. Padahal sekretaris desa merupakan merupakan perangkat desa yang mempunyai tugas pokok dan fungsi membantu kepala desa/kelurahan dalam penyelenggaraan pemerintahan desa, khususnya dalam perumusan perencanaan pembangunan desa serta penertiban administrasi keuangan dan perkantoran, perumusan peraturan dan pelayanan masyarakat.
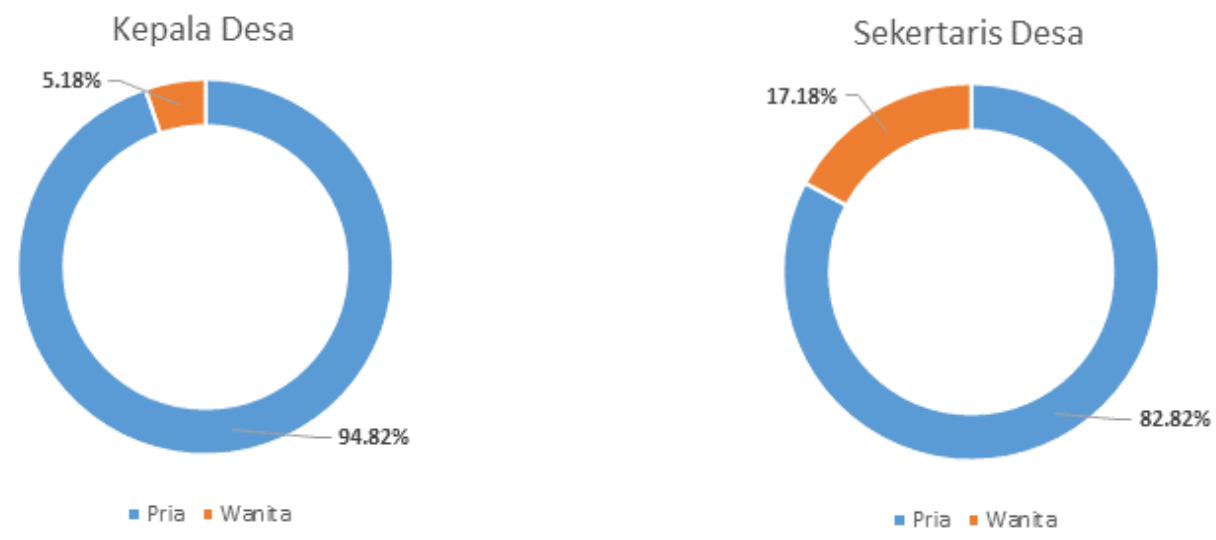

Gambar 1. Kepala Desa dan Sekertaris Desa Berdasarkan Jenis kelamin Sumber: diolah dari data Statistik Potensi Desa Kalimantan Timur (2018) 
Berdasarkan Gambar 1, secara umum kepala desa/lurah di wilayah Kalimantan Timur adalah laki-laki $(94,82 \%)$ dan mempunyai sekretaris desa laki-laki $(82,82 \%)$. Namun demikian, beberapa wilayah dipimpin oleh kepala desa perempuan $(5,18 \%)$ dan sekretaris desa perempuan $(17,18 \%)$. Hal ini menunjukkan perempuan diberikan kesempatan untuk menjadi pemimpin dan pengurus desa.

\section{Umur Kepala Desa/Lurah}

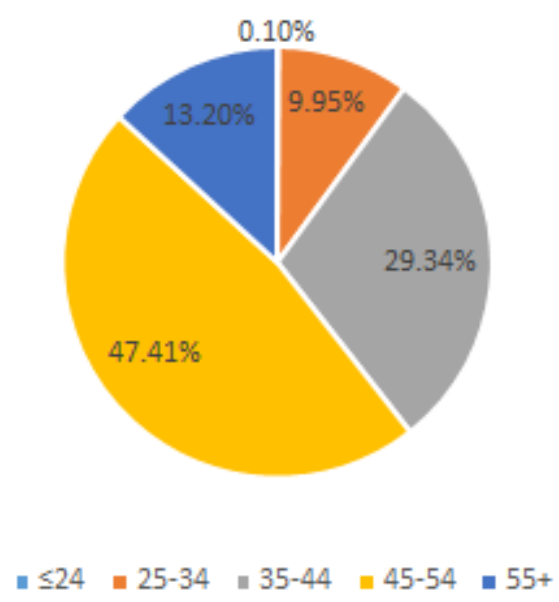

Umur Sekretaris Desa

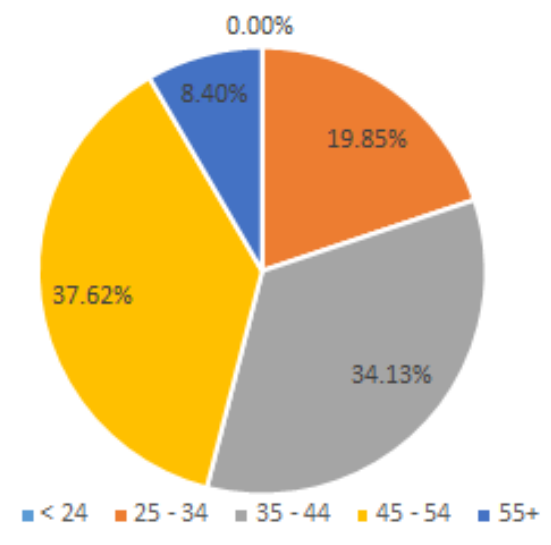

Gambar 2. Umur Kepala Desa/Lurah dan Sekretaris Desa/Lurah Sumber: diolah dari data Statistik Potensi Desa Kalimantan Timur (2018)

Berdasarkan Gambar 2, kepala desa di wilayah pedesaan Kalimantan Timur sebagian besar berumur 45-54 tahun (47,41\%), diikuti kepala desa berumur 35-44 tahun (29,34\%), diatas 55 tahun (13,2\%). Umur 45-54 tahun merupakan umur ideal kepala desa ditinjau dari kematangan dan usia produktif. Sekretaris desa di wilayah pedesaan Kalimantan Timur sebagian besar berumur 45-54 tahun (37,62\%), diikuti umur 35-44tahun (34,13\%), diatas $25-34$ tahun $(19,82 \%)$. Proporsi umur sekretaris desa secara umum lebih rendah dari umur kepala desa. Kemampuan aparatur pemerintah sebenarnya tidak terlepas dari pembicaraan tingkat kematangan aparatur yang didalamnya menyangkut keterampilan yang diperoleh dari pendidikan latihan dan pengalaman.

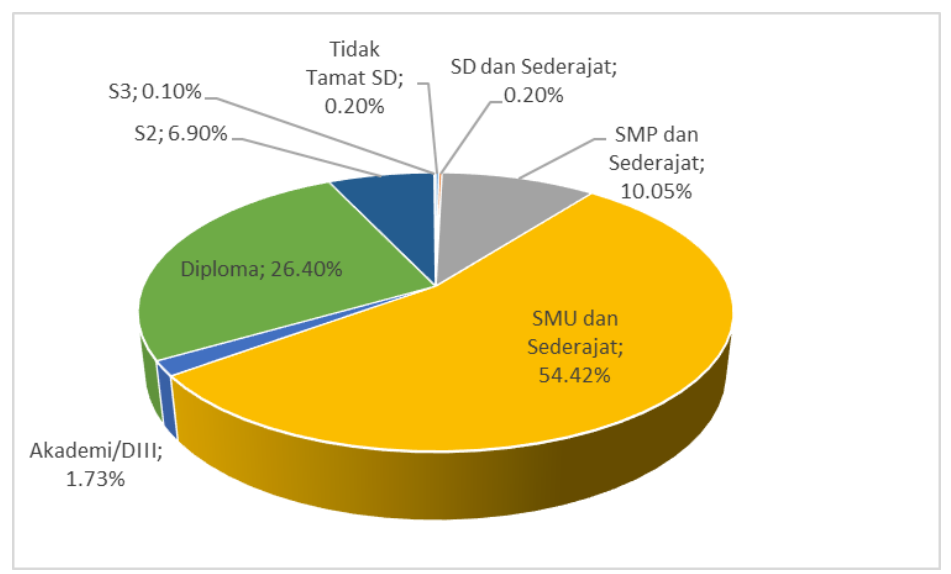

Gambar 3. Pendidikan Kepala Desa dan Sekretaris Desa Tahun 2018 Sumber: diolah dari data Statistik Potensi Desa Kalimantan Timur (2018)

Ditinjau dari tingkat pendidikan perangkat desa di Kalimantan Timur (Gambar 3), kapasitas perangkat desa cukup memadai, dimana 54,42\% berpendidikan SMU dan sederajat, $26,40 \%$ berpendidikan diploma atau Sarjana, 10,05\% berpendidikan SMP dan sederajat, bahkan 
da yang berpendidikan S2 $(6,90 \%)$ dan S3 (1 orang atau 0,10\%), sedangkan perangkat desa yang berpendidikan SD atau tidak tamat SD hanya $0,40 \%$.

\section{Pemetaan Kapasitas Perangkat Desa}

\subsection{Kapasitas Perencanaan}

Kemampuan Aparatur Desa dalam Penyusunan RPJM Desa diperlukan seperti dalam penyusunan RPJM Desa maupun RKP Desa. RPJM Desa merupakan dokumen perencanaan pembangunan jangka menengah yang digunakan untuk jangka waktu 5 (lima) tahun, sedangkan RKP Desa yang merupakan penjabaran dari RPJM Desa berfungsi untuk waktu 1 (satu) tahun. Dokumen RPJM Desa disusun oleh pemerintah desa dan Badan Permusyawaratan Desa (BPD) dan ditetapkan dengan Peraturan Desa (Perdes). Tahap penyusunan RPJM Desa diawali dengan analisis potensi dan masalah desa yang dilakukan oleh segenap Lembaga Masyarakat Desa (LMD) yang ada di desa yang bersangkutan. Hasil analisis potensi dan masalah kemudian dijadikan bahan menyusun konsep RPJM Desa, yang kemudian disampaikan kepada kepala desa. Selanjutnya, rancangan/konsep ini dibahas bersama-sama dengan BPD untuk mendapat persetujuan. Hasil kesepakatan Pemerintah Desa dengan Badan Permusyawaratan Desa dituangkan dalam Peraturan Desa (Perdes). Dokumen RPJM Desa memuat: (1) Dasar kebijakan pembangunan tingkat Kecamatan dan Kabupaten/Kota; (2) Gambaran umum keadaan desa; (3) Gambaran arah kegiatan pembangunan desa selama $3 \mathrm{~s} / \mathrm{d} 5$ tahun; (4) Jenis program/kegiatan yang akan dilakukan selama kurun waktu 3 s/d 5 tahun dilengkapi perkiraan volume, jumlah, sasaran waktu pelaksanaan dan perkiraan besarnya dana yang akan digunakan; (5) Jenis kegiatan hasil identifikasi masyarakat melalui musrenbang desa, baik yang dibiayai ataupun tidak dibiayai masyarakat dalam jangka pendek.

RKP Desa merupakan penjabaran dari RPJM Desa dan mengacu pada Rencana Kerja Pembangunan Daerah (RKPD), memuat rancangan kerangka ekonomi desa, prioritas pembangunan desa, rencana kerja, dan pendanaannya, baik yang dilaksanakan langsung oleh pemerintah desa maupun yang ditempuh dengan mendorong partisipasi masyarakat. RKP Desa disusun berdasarkan skala prioritas kebutuhan dalam pengembangan potensi yang dimiliki maupun prioritas pemecahan permasalahan yang dihadapi serta sesuai dengan kesepakatan yang tertuang dalam dokumen RPJM Desa. Penyusunan RKP Desa dilaksanakan secara partisipatif dalam wadah musyawarah perencanaan pembangunan (musrenbang). Musrenbang berfungsi sebagai forum untuk menampung, mendapatkan, membahas aspirasi/usulan kegiatan serta memutuskan usulan prioritas kegiatan di tingkat desa.

Tabel 2. Ketersediaan Rencana Pembangunan Jangka Menengah Desa (RPJM Desa) dan Rencana Kerja Pembangunan Desa (RKP Desa) Tahun 2017

\begin{tabular}{lrrrrr}
\hline \multirow{2}{*}{ Kabupaten } & $\begin{array}{r}\text { Jumlah } \\
\text { Desa }\end{array}$ & \multicolumn{2}{c}{$\begin{array}{c}\text { Rencana Pembangunan Jangka } \\
\text { Menengah Desa (RPJM Desa) }\end{array}$} & $\begin{array}{r}\text { Rencana Kerja Pembangunan Desa } \\
\text { (RKP Desa) }\end{array}$ \\
\cline { 2 - 7 } & Jumlah & Jumlah & Persen (\%) & Jumlah & Persen (\%) \\
\hline (1) & $(2)$ & $(3)$ & $(4)=(3) /(2) \times 100 \%$ & 136 & $(6)=(5) /(2) \times 100 \%$ \\
\hline Paser & 139 & 136 & 97.84 & 184 & 97.84 \\
Kutai Barat & 190 & 186 & 97.89 & 96.84 \\
Kutai Kartanegara & 193 & 190 & 94.45 & 187 & 96.89 \\
Kutai Timur & 139 & 132 & 93.00 & 88 & 92.81 \\
Berau & 100 & 93 & 100.00 & 28 & 88.00 \\
Penajam PaserUtara & 30 & 30 & 96.00 & 48 & 93.33 \\
Mahakam Hulu & 50 & 48 & $\mathbf{9 6 . 7 9}$ & $\mathbf{8 0 0}$ & 96.00 \\
\hline KALIMANTAN TIMUR & $\mathbf{8 4 1}$ & $\mathbf{8 1 4}$ & $\mathbf{9 5 . 1 2}$ \\
\hline
\end{tabular}

Sumber: diolah dari data Statistik Potensi Desa Kalimantan Timur (2018)

Berdasarkan data Potensi Desa (BPS, 2018) (Tabel 2) dapat diketahui bahwa sebagian besar pemerintah desa telah melaksanakan penyusunan dokumen-dokumen perencanaan pembangunan 
desa. Hampir semua pemerintah desa telah mempunyai dokumen RPJM Desa (96,79\%), dan dokumen RKP Desa $(95,12 \%)$. Berdasarkan hasil wawancara dengan staf Kecamatan Penajam (Ali, wawancara, 21-7-2019), masalah yang dialami di desa-desa di Kabupaten Penajam Paser Utara adalah kekurangan tenaga teknis dan kurangnya kemampuan sumberdaya aparatur dalam membuat Rencana Anggaran Proyek (RAP) dan menggambar desain. Persoalan tersebut juga menjadi hambatan bagi desa yang berdampak perencanaannya terlambat. Desa mensiasati kondisi tersebut dengan membayar tenaga ahli konsultan, termasuk hononarium, pembiayaan operasional lapangan dan alat Tulis Kantor (ATK). Menurut Ali (wawancara, 21-7-2019), seharusnya dari RKP diperoleh RAP dan gambar desain sebelum budgeting. Namun dalam kenyataannya, setelah APBDes desa baru mulai perencanaan.

Masalah yang hampir sama dikemukakan Sekretaris Dinas Pemberdayaan Masyarakat dan Kampung Kabupaten Kutai Barat (Sofyan, wawancara, 17-7-2019), terdapat beberapa masalah berkaitan dengan pelaksanaan anggaran desa, yaitu: (1) kebiasaan aparatur desa adalah menunggu angka pasti dari anggaran pusat dan daerah. Setelah anggaran desa tersedia, aparatur desa baru mengajukan APBDes. Hal ini karena aparatur desa tidak mau mengubah dokumen yang tidak mudah dilakukan. Aparatur desa tersebut belum menggunakan asumsi-asumsi seperti penganggaran di kabupaten atau provinsi. (2) Masalah lain adalah kemampuan untuk menentukan skala prioritas anggaran desa, serta (3) ada kecenderungan untuk mempertahankan status tertinggal untuk mendapatkan porsi anggaran yang lebih besar dibanding desa-desa yang statusnya sudah naik

\subsection{Kapasitas Manajemen Keuangan}

Kapasitas manajemen keuangan dan kekayaan desa adalah berkaitan dengan kapasitas manajemen operasional, kapasitas pembiayaan dan kapasitas investasi. Secara garis besar ruang lingkup manajemen keuangan desa meliputi aspek perencanaan dan penganggaran, aspek pelaksanaan dan penatausahaan, aspek pertanggungjawaban seluruh kegiatan yang berkenaan dengan pengelolaan sumber-sumber pendapatan dan biaya-biaya yang ada dalam kegiatan pemerintahan desa.

Aspek perencanaan dan penganggaran terutama dalam penyusunan Anggaran Pendapatan dan Belanja Desa (APBDes). Aparatur desa tidak hanya menghadapi tantangan dalam mengalokasikan APBDes yang terbatas, namun juga bagaimana mengoptimalkan kekayaan desa yang dimiliki. Penyusunan APBDes dengan mengacu kepada dokumen RKP Desa. APBDes adalah rencana keuangan tahunan pemerintahan desa yang dibahas dan disetujui oleh pemerintah desa dan BPD, yang ditetapkan dengan Peraturan Desa. Rancangan APBDes dibahas dalam musyawarah perencanaan pembangunan desa. Kepala Desa bersama BPD menetapkan APBDes setiap tahun dengan Peraturan Desa. Pedoman APBDes, perubahan APBDes, perhitungan APBDes dan pertanggungjawaban pelaksanaan APBDes ditetapkan dengan Peraturan Bupati/Walikota. APBDes adalah dokumen yang disusun untuk menterjemahkan kegiatan di dalam RKP Desa menjadi alokasi anggaran kegiatan/program.

Sumber pendapatan desa yang menjadi komponen APBDes terdiri atas: (a) Pendapatan Asli Desa terdiri dari hasil usaha desa, hasil kekayaan desa, hasil swadaya dan partisipasi, hasil gotong royong dan lain-lain pendapatan desa yang sah, (b) bagi hasil pajak kabupaten/kota paling sedikit 10 persen dan dari retribusi kabupaten/kota, sebagian diperuntukkan bagi desa, (c) bagian dari dana perimbangan keuangan pusat dan daerah yang diterima oleh kabupaten/kota untuk desa paling sedikit 10 persen, yang pembagiannya untuk setiap desa secara proporsional yang merupakan alokasi dana desa; dan (d) bantuan keuangan dari Pemerintah, pemerintah provinsi, dan pemerintah kabupaten/kota dalam rangka pelaksanaan urusan pemerintahan, dan (e) hibah dan sumbangan dari pihak ketiga yang tidak mengikat. 
Tabel 3. Sumber Dana Desa

\begin{tabular}{|c|c|c|c|c|c|c|c|c|c|}
\hline \multirow{2}{*}{ Wilayah } & \multicolumn{9}{|c|}{ Uraian*) } \\
\hline & 1 & 2 & 3 & 4 & 5 & 6 & 7 & 8 & 9 \\
\hline \multicolumn{10}{|l|}{ Jumlah (n) } \\
\hline Paser & 139 & 139 & 49 & 132 & 136 & 2 & 2 & 12 & 10 \\
\hline Kutai Barat & 190 & 189 & 11 & 3 & 170 & 1 & 22 & 21 & 5 \\
\hline Kutai Kartanegara & 193 & 193 & 48 & 164 & 188 & 4 & 14 & 18 & 6 \\
\hline Kutai Timur & 139 & 139 & 8 & 1 & 127 & 3 & 42 & 18 & - \\
\hline Berau & 100 & 100 & 15 & 96 & 94 & 5 & 88 & 23 & 13 \\
\hline Penajam Paser Utara (PPU) & 30 & 30 & 20 & 1 & 30 & - & - & 1 & 12 \\
\hline Mahakam Hulu & 50 & 49 & 7 & 1 & 37 & 4 & 9 & - & 2 \\
\hline Kalimantan Timur & 841 & 839 & 158 & 398 & 782 & 19 & 177 & 93 & 48 \\
\hline \multicolumn{10}{|l|}{ Persen (\%) } \\
\hline Paser & & 100.00 & 35.25 & 94.96 & 97.84 & 1.44 & 1.44 & 8.63 & 7.19 \\
\hline Kutai Barat & & 99.47 & 5.79 & 1.58 & 89.47 & 0.53 & 11.58 & 11.05 & 2.63 \\
\hline Kutai Kartanegara & & 100.00 & 24.87 & 84.97 & 97.41 & 2.07 & 7.25 & 9.33 & 3.11 \\
\hline Kutai Timur & & 100.00 & 5.76 & 0.72 & 91.37 & 2.16 & 30.22 & 12.95 & - \\
\hline Berau & & 100.00 & 15.00 & 96.00 & 94.00 & 5.00 & 88.00 & 23.00 & 13.00 \\
\hline Penajam Paser Utara (PPU) & & 100.00 & 66.67 & 3.33 & 100.00 & - & - & 3.33 & 40.00 \\
\hline Mahakam Hulu & & 98.00 & 14.00 & 2.00 & 74.00 & 8.00 & 18.00 & - & 4.00 \\
\hline Kalimantan Timur & & 99.76 & 18.79 & 47.32 & 92.98 & 2.26 & 21.05 & 11.06 & 5.71 \\
\hline
\end{tabular}
Keterangan: *

1. Jumlah Desa

Sumber dana desa:

2. Dana Desa (DD) Bersumber dari APBN

3. Pendapatan Asli Desa (PADes)

4. Bagian dari Hasil Pajak Daerah dan Retribusi Daerah

5. Alokasi Dana Desa (ADD)

6. Bantuan Keuangan dari APBD Provinsi

7. Bantuan Keuangan dari APBD Kabupaten

8. Hibah dan Sumbangan dari Pihak Ketiga

9. Lain-Lain Pendapatan Desa yang Sah

Sumber: diolah dari data Statistik Potensi Desa Kalimantan Timur (2018)

Jumlah desa yang mempunyai sumber dana desa yang berasal dari Pendapatan Asli Desa (PADes) baru sebanyak 18,79\% (Tabel 3). Menurut hasil wawancara dengan staf Dinas Pemberdayaan Masyarakat dan Desa (PMD) Provinsi Kalimantan Timur (Huzaimah, wawancara, 10-7-2019) dapat diketahui bahwa selama ini aparatur desa belum terbiasa dan kreatif dalam mencari pendapatan asli desa. Beberapa hal yang dimuat dalam keuangan desa merupakan hal yang baru bagi perangkat desa.

Sumber pendapatan desa yang menjadi komponen APBDes sebagian besar berasal dari APBN dan Alokasi Dana Desa (ADD) dengan rata-rata pencairan masing-masing sebesar 99,76\% dan 92,98\% (Tabel 3). Menurut hasil wawancara dengan staf Dinas Pemberdayaan Masyarakat dan Desa Provinsi Kalimantan Timur (Huzaimah, wawancara, 10-7-2019) alokasi dana desa sampai saat ini dalam penyalurannya tidak menemui hambatan yang berarti. Beberapa kasus keterlambatan dalam pencairan dikarenakan adanya keterlambatan laporan pertanggungjawaban dari desa itu sendiri. Kasus keterlambatan diantaranya terjadi di Kabupaten PPU pada tahun 2017 ketika pemotongan anggaran menyebabkan pemerintah Kabupaten PPU tidak mampu membayar pada tahun berjalan dan menjadi hutang yang kemudian dibayarkan pada tahun berikutnya. Selanjutnya Huzaimah (wawancara, 10-7-2019), menambahkan bahwa di tingkat desa persoalan dalam ADD adalah: (1) keterlambatan dalam pelaporan pertanggungjawaban keuangan desa yang berdampak terlambatnya pencairan ADD triwulan berjalan. Keterlambatan tersebut lebih banyak disebabkan oleh kemampuan SDM aparatur desa yang terbatas, (2) masalah lain adalah adanya penggantian perangkat desa yang sudah mengikuti diklat dan pelatihan oleh kepala desa terpilih dengan pengurus baru yang belum pernah mengikuti pelatihan sehingga terjadi kesulitan dalam pelaporan keuangan. Hambatan di tingkat pemerintah kecamatan dan dinas adalah terbatasnya 
anggaran untuk monitoring. Adapun permasalahan utama yang dihadapi Dinas PMD adalah minimnya anggaran sehingga pengumpulan data terhambat karena tidak adanya anggaran untuk monitoring dan evaluasi ke daerah menyangkut Alokasi Dana Desa (Huzaimah, wawancara, 107-2019).

Menurut wawancara pendamping desa di Kecamatan Tenggarong Seberang (Ali, wawancara, 17-7-2019), dari sisi penggunaan sudah ada Permendes yang mengatur alokasi ADD antara peruntukan pembangunan infrastruktur dan pemberdayaan. Masalah keterlambatan penyaluran dana di tingkat desa, lebih disebabkan kapasitas aparatur desa dan pendamping desa. Ali (wawancara, 17-7-2019) juga menambahkan bahwa selain kemampuan SDAP desa, pergantian aparat dan kapasitas anggaran juga berpotensi mempengaruhi keterlambatan penyaluran dana desa.

"Dana desa bisa dikelola dengan lebih baik dengan kemampuan SDAP desa yang tinggi. Dari segi aparatur desa memang penuh dengan keterbatasan walaupun tidak lagi seringnya pergantian aparat tetapi pelatihan peningkatan kapasitas dari kabupaten maupun propinsi semakin sedikit karena keterbatasan anggaran dan desa menggunakan dana desa untuk peningkatan SDAP-nya. Harapan untuk pemerintah desa yang profesional sudah diupayakan sepeti pada tahun ini kasi/kaur mulai membuat DPA walaupun baru tahun ini tetapi merupakan kemajuan yang memberikan harapan bahwa pemerintah desa mempunyai komitmen dalam perspektif kedepan dan peningkatan SDAP desa.” (Ali, wawancara, 17-7-2019)

Selanjutnya pendamping desa di Kecamatan Tenggarong Seberang (Ali, wawancara, 17-72019) menambahkan pentingnya azas efektif dan efisien dalam pengelokasian Dana Desa dalam pembangunan desa untuk kemandirian desa. Pelatihan aparatur bukan hanya teknis, seperti: teknis pelaporan dalam sistem informasi keuangan, namun yang lebuh penting adalah manajemen (penganggaran, investasi) untuk efektifitas pembangunan dan kemandirian desa.

“ mohon maaf menurut saya pelatihan-pelatihan yang diberikan cenderung teknis nanti persoalan yang muncul adalah masalah teknis atau terjebak ke teknis. Padahal keberhasilan desa karena SDAP nya bukan karena sistemnya. Tidak mesti by sistem. Oleh karena itu pengembangan SDAP harusnya dinamis mengikuti perkembangan dan partisipasi masyarakat di desa juga penting untuk keberhasilan pemerintah desa..." (Ali, wawancara, 17-7-2019)

Pengalaman lain dikemukakan oleh Kasie ADD Dinas Pemberdayaan Masyarakat dan Desa Kabupaten PPU (Suherman, wawancara, 19-7-2019) yang mengemukakan bahwa penetapan pagu indikatif untuk ADD tahun 2019 seharusnya adalah pada tahun 2018 di bulan November, sedangkan pagu indikatif paling lambat di bulan Desember. Desa seharusnya menetapkan pagu APBDes-nya di tahun sebelumnya Namun kenyataannya, desa baru dapat menentukan pagu indikatif di bulan Desember. Hasil ini terjadi karena proses untuk menunggu pagu indikatif dari desa dan proses definitif dengan peraturan bupati yang agak lama. Temuan permasalahan lain adalah penyusunan APBDes dengan BPD dan proses pengajukan ke Kasie ADD Dinas Pemberdayaan Masyarakat dan Desa baru di bulan ke-4. Hal ini menyebabkan definitifnya terlambat baru di bulan April. Hal tersebut menyebabkan pencairan ke desa baru dapat dijalankan di bulan April atau bulan Mei. Menurut Suherman (2019), selain keterlambatan karena penentuan pagu ADD di kabupaten juga terdapat kendala di desa dalam penyusunan APBDes-nya karena ada tarik menarik kepentingan para pihak di desa.

Menurut staf Kecamatan Penajam (Ali, wawancara, 21-7-2019), terdapat 4 (empat) desa dalam Kecamatan Penajam yaitu Desa Girimukti, Giripurwa (Pemekaran), Sidorejo dan Desa Bukitsubur yang melakukan proses APBDes selalu diawal tahun dimulai dari musrenbangdes 
penetapan RAPBDes dan APBDes-nya di tahun berjalan. Proses tersebut sebenarnya dapat dilaksanakan di akhir tahun sebelumnya seperti di Desember dan berlaku di bulan Januari. Hal tersebut karena desa menunggu pagu indikatif dulu baru mulai memproses RAPBDes, sehingga penetapan APBDes terlambat. Menurut staf Kecamatan Penajam (Ali, wawancara, 21-7-2019), musrenbangdes di desa selama ini lancar dan tidak ada hambatan. Desa biasanya menunggu bocoran informasi dan menggunakan dasar tahun sebelumnya. Aparatur desa tetap menyusun RAPBDes. Selanjutnya setelah pagu ditetapkan. aparatur desa tinggal revisi sesuai nilai yang sudah dipastikan. Ali (wawancara, 21-7-2019) juga menambahkan bahwa hambatan lain dalam dokumen adalah dalam pembuatan Surat Pertanggung Jawaban (SPJ) desa serta sering terlambat dalam setor pajak, serta persyaratan administrasi sampai pemeriksaan yang belum selesai. Jika SPJ sudah ada, pihak kecamatan selanjutnya melakukan pengecekan dan menunggu sampai kelengkapan cukup sebelum keluar surat rekomendasi dari kecamatan. Pencairan ADD dalam 2 (dua) tahap yaitu 70\% dan 30\% sedangkan DD dalam tiga tahap yaitu 20\%, 40\% dan 40\%.

Dalam pelaksanaan dan penatausahaan keuangan desa, menurut Permendagri No. 32 Tahun 2006 mengenai Pedoman Administrasi Desa, setidaknya terdapat tujuh macam administrasi keuangan desa, yakni Buku Anggaran Penerimaan, Buku Anggaran Pengeluaran Rutin, Buku Anggaran Pengeluaran Pembangunan, Buku Kas Umum, Buku Kas Pembantu Penerimaan, Buku Kas Pembantu Pengeluaran Rutin, dan Buku Kas Pembantu Pengeluaran Pembangunan. Setidaknya bentuk-bentuk administrasi desa tersebut menjadi kompetensi yang wajib dimiliki oleh aparatur desa. Pelaksanaan dan penatausahaan keuangan desa yang juga pemegang kekuasaan penyelenggaraan pemerintahan desa dan pemegang kekuasaan dalam pengelolaan keuangan desa adalah kepala desa. Selanjutnya dalam pelaksanaannya. kepala desa dibantu oleh bendarawan desa, perangkat desa beserta masyarakat.

Dalam aspek pertanggungjawaban keuangan desa, kepala desa adalah sebagai pemegang kekuasaan penyelenggaraan keuangan desa wajib menyampaikan pertanggungjawabannya kepada bupati/walikota melalui camat, dalam rangka pengelolaan keuangan desa yang akuntabilitas dan transparan. Pelaksanaan ADD wajib dilaporkan kepada Bupati melalui Camat (atau BPMPDes). Laporan pelaksanaan tersebut terdiri dari Laporan Kemajuan Fisik, Laporan Bulanan, dan Laporan Pertanggungjawaban. Pelaporan dilaksanakan untuk mengetahui perkembangan proses pengelolaan dan penggunaan ADD yang mencakup perkembangan kegiatan dan penyerapan dana, masalah yang dihadapi dan pemecahannya, pencapaian hasil penggunaan ADD.

Menurut Sekretaris Dinas Pemberdayaan Masyarakat dan Desa Kabupaten Paser (Jarkawi, wawancara, 21-7-2019), masalah-masalah yang dihadapi desa berkaitan dengan penyaluran ADD di Kabupaten Paser adalah masalah kelengkapan laporan pertanggungjawaban. Terdapat dua desa yang diaudit oleh inspektorat wilayah karena keterlambatan SPJ dan BPKP (Badan Pemeriksa Keuangan) juga masuk ke empat desa yang sudah kategori maju (bagus) untuk sampling yaitu dua di Kecamatan Longikis dan dua di Kecamatan Grogot.

Masalah lain adalah dalam penyusunan RAP di desa belum memiliki SDAP yang mampu sehingga menggunakan jasa konsultan. Dan karena pekerjaan Kekurangan pembayaran pernah terjadi di tahun 2017 dan dibayarkan pada tahun 2018. Peran kecamatan adalah untuk mengevaluasi APBDes serta memverifikasi dokumen untuk pengajuan anggaran dan menerbitkan rekomendasi pembayaran. Apabila dokumen pengajuan dari desa tidak lengkap dapat mengakibatkan keterhambatan proses di kecamatan. Masalah yang sama dikemukakan oleh Sekdes Girimukti Kabupaten Penajem (Sarimiarti, wawancara, 21-7-2019) masalah dalam perencanaan RAP yaitu masih menggunakan jasa konsultan dalam perencanaan RAP fisiknya. 


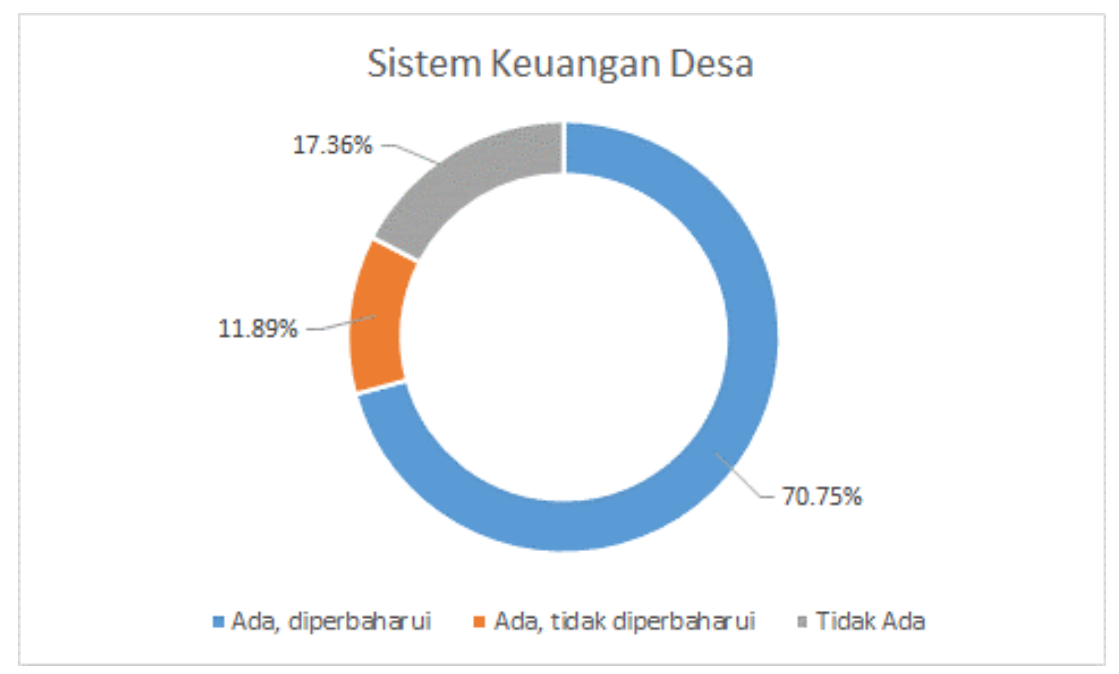

Gambar 4. Ketersediaan Sistem Keuangan Desa di wilayah Perdesaan Kalimantan Timur Tahun 2017 Sumber: diolah dari data Statistik Potensi Desa Kalimantan Timur (2018)

Berdasarkan data Statistik Potensi Desa Kalimantan Timur (BPS, 2018) (Gambar 4), sebagian besar $(70,75 \%)$ desa di Kalimantan Timur telah menerapkan Sistem Keuangan Desa (Siskeudes) dan diperbaharui secara periodik. Sistem Keuangan Desa (Siskeudes) merupakan aplikasi yang dikembangkan Badan Pengawasan Keuangan dan Pembangunan (BPKP) dalam rangka meningkatkan kualitas tata kelola keuangan desa. Sebanyak 11,89\% desa telah tersedia Siskeudes, namun belum diperbarui secara periodik. Sebanyak 17,36\% desa belum tersedia Siskeudes. Hal ini disebabkan banyak aparatur desa belum siap dan terbiasa dalam penggunaan aplikasi-aplikasi yang masih baru seperti Siskeudes (Suherman, wawancara, 21-7-2019).

Menurut wawancara Sekdes Girimukti Kabupaten Penajem (Sarimiarti, 2019), pengelolaan potensi desa untuk menambah pendapatan desa dapat dikatakan juga masih belum optimal. Untuk meningkatkan pendapatan masyarakat dan desa, pemerintah desa dapat mendirikan Badan Usaha Milik Desa (BUMDes), yakni usaha desa yang dikelola oleh pemerintah desa. BUMDes yang diharapkan dapat meningkatkan pendapatan asli desa juga belum terkelola dengan baik. Akhirnya, dari sisi penerimaan keuangan desa masih sangat bergantung dari transfer pemerintah yang ada di atasnya. Pelaksanaan dan penatausahaan keuangan desa, administrasi desa juga belum terselenggara dengan baik, pelaporan dan pertanggungjawaban keuangan desa juga belum dilakukan dengan baik. Terkait dengan administrasi kekayaan desa, terdapat bebagai dokumen administrasi yang mesti dilaksanakan oleh pemerintah desa, yakni Buku Data Tanah Milik Desa/Tanah Kas Desa, Buku Data Inventaris Desa, dan Buku Data Tanah di Desa. Kemampuan administrasi ini perlu dikuasai oleh aparat desa. Adapun biaya pengelolaan kekayaan desa dibebankan kepada APBDes.

\subsection{Kapasitas Kebijakan Desa}

Dilihat dari jenis produk hukum yang ada di desa, terdapat dua jenis kebijakan yakni, kebijakan yang bersifat mengatur dan kebijakan yang bersifat menetapkan. Kebijakan yang bersifat mengatur terdiri dari Peraturan Desa dan Peraturan Kepala Desa, sedangkan kebijakan yang bersifat menetapkan adalah Keputusan Kepala Desa. Adapun pengertian dari masing-masing kebijakan (produk hukum) tersebut dapat diuraikan secara singkat sebagai berikut:

a. Peraturan Desa (Perdes), adalah peraturan perundang-undangan yang dibuat oleh Kepala Desa bersama-sama dengan Badan Permusyawaratan Desa, yang memuat seluruh materi penyelenggaraan pemerintahan desa, pembangunan desa, dan pemberdayaan masyarakat, serta penjabaran lebih lanjut dari ketentuanperundang-undangan yang lebih tinggi;

b. Peraturan Kepala Desa, adalah peraturan perundang-undangan yang ditetapkan oleh Kepala Desa yang sifatnya mengatur dalam rangka melaksanakan Peraturan Desa dan peraturan 
perundang-undangan yang lebih tinggi, muatan materi dari Peraturan Kepala Desa adalah penjabaran pelaksanaan Peraturan Desa;

c. Keputusan Kepala Desa, adalah keputusan yang ditetapkan oleh Kepala Desa yang bersifat menetapkan dalam rangka melaksanakan peraturan desa maupun peraturan kepala desa, dilihat dari muatan materi keputusan kepala desa ini adalah penjabaran pelaksanaan peraturan desa dan peraturan kepala desa yang bersifat penetapan.

Sedangkan ditinjau dari proses penyusunan kebijakan desa baik Peraturan Desa, Peraturan Kepala Desa maupun Keputusan Kepala Desa mengikuti proses dan pentahapan mulai dari tahapan persiapan dan pembahasan, pengesahan dan penetapan, penyampaian dan penyebarluasan. Berdasarkan Peraturan Pemerintah Nomor 72 Tahun 2005 tentang Desa, paling tidak terdapat beberapa Kebijakan Desa yang harus disusun oleh setiap desa, yakni Peraturan Desa tentang Anggaran Pendapatan dan Belanja Desa (APBDes), Peraturan Desa tentang RPJMDes, Peraturan Desa tentang Perubahan APBDes, Peraturan Desa tentang Pengelolaan Keuangan Desa, Peraturan Desa tentang BUMDes, Peraturan Desa tentang Hubungan Kerjasama Desa, Peraturan Kepala Desa tentang Pertanggungjawaban Pelaksanaan APBDes, dan Keputusan Kepala Desa sebagai tindak lanjut dari Peraturan Desa dan peraturan perundang-undangan lainnya.

Tabel 5. Ketersediaan Produk Peraturan Kepala Desa di wilayah Perdesaan Kalimantan Timur Tahun 2017

\begin{tabular}{lrrr}
\hline Wilayah & $\begin{array}{r}\text { Jumlah } \\
\text { Desa }\end{array}$ & $\begin{array}{r}\text { Peraturan } \\
\text { Kepala Desa }\end{array}$ & $\begin{array}{r}\text { Rata-rata Produk } \\
\text { Peraturan/Desa (x) }\end{array}$ \\
\hline$(1)$ & $(2)$ & $(3)$ & $(4)=(3) /(2)$ \\
\hline Paser & 139 & 114 & 0.82 \\
Kutai Barat & 190 & 113 & 0.59 \\
Kutai Kartanegara & 193 & 157 & 0.81 \\
Kutai Timur & 139 & 72 & 0.52 \\
Berau & 100 & 40 & 0.40 \\
Penajam Paser Utara & 30 & 15 & 0.50 \\
Mahakam Hulu & 50 & 31 & 0.62 \\
\hline Kalimantan Timur & $\mathbf{8 4 1}$ & $\mathbf{5 4 2}$ & $\mathbf{0 . 6 1}$ \\
\hline
\end{tabular}

Sumber: diolah dari data Statistik Potensi Desa Kalimantan Timur (2018)

Berdasarkan data Podes Tahun 2018 (Tabel 5), jumlah produk peraturan kepala desa sebanyak 542 dari 841 desa di Kalimantan Timur. Rata-rata jumlah peraturan kepala desa per desa adalah $0,61 \mathrm{x}$ (rasio < 1) menunjukkan bahwa belum semua desa menerbitkan peraturan kepala desa setiap tahun anggaran terutama berkaitan dengan pertanggungjawaban pelaksanaan APBDes. Tingkat pemahaman perangkat desa terhadap regulasi desa masih terbatas pada regulasi yang dibuat oleh pemerintah desa yaitu Peraturan Desa dan Keputusan Kepala Desa. Berdasarkan hasil diskusi dengan para Kepala Desa dapat diungkap beberapa kebutuhan pengembangan kapasitas aparatur desa dalam hal perumusan kebijakan desa, antara lain: (1) Kemampuan memetakan masalah dan potensi desa (sumber-sumber ekonomi desa, sosial-politik desa, budaya); (2) Kemampuan memahami isu-isu yang berkembang di masyarakat desa (3) Kemampuan menguasai tata naskah dinas; (4) Kemampuan menguasai proses dan prosedur legal drafting (untuk penyusunan Perdes, Perkades dan Keputusan Kades); (5) Kemampuan menguasai berbagai kebijakan pemerintah daerah, seperti RPJM Kabupaten, RKPD Kabupaten, RPJM Desa, RKP Desa, dll; (6) Kemampuan membangun persepsi yang sama antara Pemerintah Desa dan BP.

\subsection{Manajemen Pelayanan Publik}

Kegiatan pelayanan yang dilaksanakan oleh instansi pemerintah baik pusat maupun daerah dalam bentuk barang maupun jasa dalam rangka pemenuhan kebutuhan masyarakat harus sesuai peraturan perundang-undangan yang berlaku. Tuntutan diatas harus dihadapi setiap pemerintah daerah, terutama pemerinah kabupaten/kota yang merupakan ujung tombak pelaksanaan asas desentralisasi sebagai daerah otonom yang mandiri dan memiliki kewenangan penuh untuk 
mengatur rumah tangganya sendiri. Dalam konteks otonomi desa, desa mempunyai kewenangan untuk mengatur dan mengurus urusan-urusan yang berkaitan dengan pemenuhan kebutuhan masyarakat.

Sementara itu berdasarkan Keputusan MENPAN Nomor 63/KEP/M.PAN/7/2003 tentang Pedoman Umum Penyelenggaraan Pelayanan Publik maka pelayanan publik dikelompokkan sebagai berikut :

1. Kelompok Pelayanan Administratif: seperti penerbitan bukti-bukti kewarganegaraan (akta kelahiran, KTP, pasport), sertifikat pengakuan atas kecakapan (kompetensi) tertentu warga yang menerimanya (ijazah, sertifikat, diploma, lisensi).

2. Kelompok Pelayanan Barang, adalah pelayanan yang menghasilkan barang tertentu yang dimanfaatkan oleh masyarakat. Misalnya: jalan raya, gedung sekolah, tempat tempat pengobatan, dan pemeliharaan kesehatan, terminal, jaringan telepon, jaringan telepon, jaringan penyaluran tenaga listrik, jaringan air bersih dan sejenisnya.

3. Kelompok Pelayanan Jasa: adalah pelayanan yang menghasilkan produk jasa tertentu yang diperlukan oleh masyarakat. Misalnya penyelenggaraan pendidikan dan pelatihan, pemeliharaan, kesehatan dan pengaturan lalu lintas.

Kemampuan perangkat desa dalam pelayanan publik belum diikuti secara baik dalam administrasi seperti dalam mengatur dan menyelenggarakan pencatatan buku-buku, karena kurang teratur dan kurang tertib serta belum sistematis. Keterbatasan kemampuan perangkat desa dalam pelayanan administrasi karena mereka belum pernah mendapat diklat/bimtek yang memadai. Salah satu kegiatan pelayanan masyarakat adalah dalam penyediaan sistem informasi desa untuk mencapai kualitas pelayanan publik yang transparan, akuntabel, dan partisipatif.

\section{Sistem Informasi Desa}

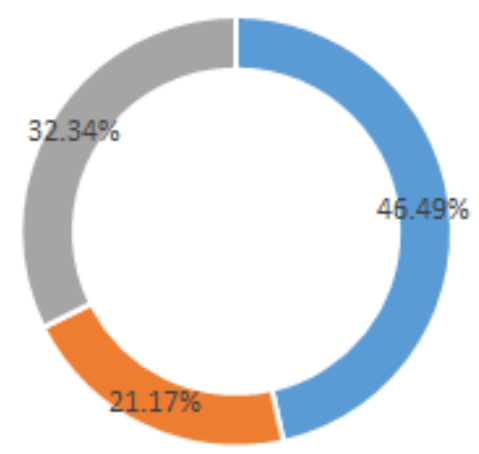

" Ada, diperbaharui = Ada, tidak diperbaharui = Tidak Ada

Gambar 5. Ketersediaan Sistem Informasi Desa di wilayah Perdesaan Kalimantan Timur Tahun 2017 Sumber: diolah dari data Statistik Potensi Desa Kalimantan Timur (2018)

Berdasarkan data Statistik Potensi Desa Kalimantan Timur (BPS, 2018) (Gambar 5), masih banyak desa (32,34\%) yang belum menerapkan Sistem Informasi Desa. Sebanyak 21,17\% telah tersedia Sistem Informasi Desa, namun tidak diperbaharui (tidak di update). Hanya sebanyak 46,49\% desa yang telah menerapkan Sistem Informasi Desa dan telah di diperbaharui secara periodik. Hal ini disebabkan banyak aparatur desa belum siap dan terbiasa dalam penggunaan aplikasi-aplikasi yang masih baru seperti Sistem Informasi Desa (Suherman, wawancara, 21-72019). Sistem Informasi Desa meliputi data desa, data pembangunan desa, kawasan perdesaan, serta informasi lain yang berkaitan dengan pembangunan desa dan pembangunan kawasan 
perdesaan. Sistem Informasi Desa dikelola oleh Pemerintah Desa dan dapat diakses oleh masyarakat desa dan semua pemangku kepentingan.

Upaya pemenuhan kebutuhan masyarakat di bidang pelayanan di tingkat desa terutama sering mengalami kendala dalam aspek kultural-geografis dan struktural. Sejauh pengamatan yang dilakukan ada beberapa faktor penyebab keterbelakangan desa. Pertama, keterbatasan jumlah staf pemerintah desa yang bertanggungjawab untuk pemerintahan desa, sementara pada sisi lain jumlah desa/kelurahan dari tahun ke tahun cenderung meningkat dengan masalah ikutannya yang juga meningkat dan kompleks. Kedua, mobilitas staf pemerintahan yang terbatas (kuantitas maupun kualitas) berpengaruh pada fungsi kendali kontrol terhadap pelaksanaan pemerintahan desa yang rendah. Ketiga, kuantitas dan kualitas pendampingan, pelatihan dan monitoring perkembangan desa yang rendah berpengaruh kepada efektifitas dan efisiensi intervensi program. Akibatnya program tidak berdampak signifikan pada pemberdayaan pemerintahan desa sehingga perjalanan tata pemerintahan desa seolah-olah tanpa visi dan misi yang terarah. Keempat, keterisolasian desa yang tinggi berpengaruh pada aksesibilitas pemukiman penduduk terhadap pusat-pusat fasilitas publik sehingga menimbulkan kesenjangan pelayanan publik. Kelima, kualitas dan kompetensi SDM desa yang masih rendah dan terbatas berpengaruh pada produktifitas dan kreatifitas aparat desa. Keenam, posisi dan ketokohan lokal yang dominan masih menjadi referensi dalam berbagai pengambilan kebijakan baik bersifat kultural maupun formal berdampak pada sistem pemerintahan desa lebih didominasi semangat feodalisme dan klientalisme.

\section{Program Peningkatan Kapasitas SDAP yang telah dilakukan}

Pengumpulan data-data sekunder ke Dinas Pemberdayaan Masyarakat dan Pemerintahan Desa Kabupaten/Kota di Kalimantan Timur berhasil memperolah data aparatur SDM desa yang telah mendapatkan peningkatan kapasitas untuk Kabupaten Paser tahun 2017 dan Kabupaten Kubar tahun 2018. Sementara kabupaten lainnya belum memberi laporan data aparatur desa yang sudah pernah diminta oleh Dinas Pemberdayaan Masyarakat dan Pemerintahan Provinsi Kalimantan Timur.

Manurut hasil wawancara dengan Dinas Pemberdayaan Masyarakat dan Pemerintahan Desa Provinsi Kalimantan Timur (Huzaimah, wawancara, 10-7-2019), terdapat beberapa kendala dalam pengembangan kapasitas sumberdaya aparatur desa yaitu: ketersediaan data, kurang koordinasi serta anggaran untuk monitoring dan evaluasi.

"Sampai saat ini belum memberi data-data aparatur desa yang berkali-kali kami minta sementara memiliki keterbatasan anggaran untuk monitoring dan evaluasi. Kegiatan pengembangan SDM di desa kurang koordinasi dengan kami karena pemerintah desa memiliki asosiasi Pemdes dengan begitu peningkatan kapasitas aparatur dikelola sendiri melalui asosiasi pemdes. Mereka melakukan pelatihan-pelatihan lewat asosiasi tersebut langsung ke Jawa" (Huzaimah, wawancara, 10-7-2019)

Hal yang sama dikemukakan oleh Kasie Pengembangan Aparatur Desa PMD Kabupaten Kutai Timur (Yudit, wawancara, 26-7-2019), banyak pelatihan di desa tanpa dokumentasi sehingga Seksi Pengembangan Aparatur Desa PMD tidak memiliki data untuk pelatihan-pelatihan yang dilakukan desa sementara keterbatasan anggaran pada dinas menyebabkan pelatihan yang diselenggarakan sedikit sekali. Seperti tahun 2018 hanya satu pelatihan yaitu Siskeudes.

Pentingnya pengembangan kapasitas SDAP desa diantaranya dikemukakan oleh Dinas Pemberdayaan Masyarakat dan Desa Provinsi Kalimatan Timur (Huzaimah, wawancara, 10-72019). Menurut Huzaimah (2019), sebanyak 10 desa berstatus mandiri di Kaltim dan status tertinggi itu terutama dimotori oleh kemampuan SDM aparatur desa sedangkan desa-desa lainnya masih dihadapkan pada keterbatasan SDM dan infrastruktur penunjangnya. 
Penggunaan DD dan ADD untuk pengembangan SDAP desa dikemukakan oleh Kades Karangtunggal Kecamatan Tenggarong Seberang (Bambang, wawancara, 18-7-2018). Menurut wawancara dengan Kades Rangan, Kabupaten Paser (Ali, wawancara, 21-7-2019), SDAP Desa Ranggan mendapatkan pelatihan-pelatihan dari kabupaten meliputi bimtek, penyusunan RKP Desa, penyusunan APBDes dan pelatihan Siskeudes di Balikpapan. Sedangkan menurut Sekretaris Camat Kuaro (Razidinnor, wawancara, 1-8-2019), pelatihan SDAP Kabupaten Pasar di Balikpapan terkait pembuatan laporan pertanggungjawaban APBDes untuk semua desa.

Menurut staf Kecamatan Penajam (Ali, wawancara, 21-7-2019), dalam peningkatan kapasitas aparatur desa melalui pelatihan-pelatihan pada saat ini dikelola Pemerintah Kabupaten. Selanjutnya Pemerintah Kabupaten menunjuk dan koordinasi ke Camat. Pelatihan dilakukan untuk peningkatan kapasitas aparatur desa, seperti: aplikasi SISKEUDES, keuangan administrasi desa dan penganggaran desa. Pelatihan-pelatihan ketrampilan tergantung dari desanya sendiri apa yang dibutuhkan. Dinas-dinas terkait selama ini siap memfasilitasi dan men-support.

Peningkatan kapasitas SDAP desa pernah dilakukan Dinas Pemberdayaan Masyarakat dan Desa Kabupaten Penajam Paser Utara (Suherman, wawancara, 21-7-2019) yaitu pada tahun 2015 dalam bentuk pelatihan pengadaan barang dan jasa. Sedangkan pelatihan saat ini banyak dilakukan melalui anggaran APBDes seperti peningkatan kapasitas BPD dan pelatihan keuangan desa (SISKEUDES). Saat ini pendapatan aparatur desa telah memenuhi ketentutan minimal ASN setara Golongan 2 untuk kades, sekdes dan kaur/kasi. Sementara untuk staf desa mengikuti patokan honor di kabupaten yaitu 1,7 juta perbulan untuk tingkat sarjana.

Sekdes Desa Girimukti Kabupaten Penajem, (Sarimiarti, wawancara, 22-7-2019) mengemukakan aparatur desa sudah semua dilatih teknis dan terdapat perencanaan dan koordinasi dengan kabupaten untuk diklat penguatan kapasitas aparatur desa. Namun demikian pada tahun 2019, peserta diklat baru melibatkan kepala desa, sedangkan penguatan kapasitas perangkat dibawahnya direncanakan dilakukan pada tahun 2020.

Menurut Kasie Pengembangan Aparatur Desa PMD Kabupaten Kutai Timur (Yudit, wawancara, 26-7-2019), pelatihan-pelatihan yang pernah diselenggarakan oleh desa diantaranya adalah pelatihan SISKEUDES dengan narasumber berasal dari Kasi Pengembangan Aparatur Desa PMD. Selain SISKEUDES, juga terdapat pelatihan penyusunan perdes tentang kewenangan desa, peningkatan kapasitas Tim Pengelola Kegiatan (TPK) desa, sosialisasi penanggulangan stunting bekerjasama dengan perusahaan Indominco, sosialisasi tupoksi Badan Permusyawaratan Desa (BPD) dan sosialisasi pengangkatan dan pemberhentian perangkat desa/lembaga kemasyarakatan desa misalnya ka dusun atau RT. Juga pelatihan pelatihan untuk BUMDes. Selanjutnya menurut Kasie Pengembangan Aparatur Desa PMD Kabupaten Kutai Timur (Yudit, wawancara, 26-72019), juga mengemukakan perlunya pelatihan terintegrasi. Selama ini pelatihan dilakukan terpisah-pisah sesuai dinas yang berkaitan.

Menurut Kasie Pengembangan Aparatur Desa PMD Kabupaten Kutai Timur (Yudit, wawancara, 26-7-2019), pelatihan yang belum pernah dilaksanakan adalah pengelolaan aset desa. Pelatihan berdasarkan prioritas karena keterbatasan anggaran. Pelatihan pada tahun 2019 masih konsentrasi di SISKEUDES karena belum semua desa mendapat pelatihan. Rencana kedepan ketika anggaran tersedia, dinas akan melaksanakan pelatihan pengelolaan aset desa karena pengelolaan aset desa penting sekali dan selama ini aparatur desa seperti melupakan pengelolaan asetnya.

Menurut staf Dinas Pemberdayaan Masyarakat dan Desa Kecamatan Tenggarong Seberang (Ali, wawancara, 21-7-2019) jumlah desa yang banyak dan wilayah yang luas di Kutai Kartanegara menjadi kendala dalam pembinaan dan pengendalian. Keterbatasan anggaran Dinas PMD maka pembinaan dan pengendalian hanya sebatas pelaporan saja sedangkan monitoring dan evaluasi kunjungan ke lapangan sangat sedikit sekali. Demikian juga dana pendampingan desa yang tidak ada menjadi keterbatasan para pendamping dalam mendampingi desa-desa. Kapasitas anggaran 
pelatihan peningkatan kapasitas dari kabupaten maupun propinsi semakin sedikit sehingga desa menggunakan dana desa untuk peningkatan SDAP nya.

Pengembangan kapasitas lainnya adalah melalui peran pendamping. Pendamping berperan penting dalam pemetaan potensi desa, perencanaan, manajemen keuangan dan pelaporan. Menurut wawancara PMD Sangata (Fitriansyah, wawancara, 27-7-2019), peran pendamping desa seperti pendampingan untuk mengurangi kesalahan dalam penyusunan APBDes. Pendamping sangat membantu kelancaran di desa. Menurut wawancara Nurdin, Sekdes Sukadamai Kecamatan Teluk Pandan (wawancara, 27-7-2019), berperan dalam mengatasi kesalahan dalam perencanaan dan implementasi program.

"Pendamping desa sangat membantu mengatasi kesalahan sebelum fatal. Pendamping lokal mencakup 3 desa untuk 1 pendamping dan di kecamatan ada 1 orang. Misalnya kalau gambar proyek tidak sesuai itu harus konsultasi dulu dengan pendamping jadi tidak semau PPK dalam kegiatan”. (Sekdes Sukadamai Kecamatan Teluk Pandan, wawancara, 27-7-2019)

PMD Sangata (Fitriansyah, wawancara, 27-7-2019), menambahkan bahwa dengan perubahan regulasi dalam Permendagri Nomor 20, maka selain DD, ADD juga harus mengikuti perubahan regulasi tersebut. Seperti berlakunya nomenklatur PPKD (Panitia Pengelola Keuangan Desa). Tetapi secara menyeluruh proses penetapan dan lain-lain itu tetap sama. Peran pendamping lain dalam membantu pelaksanaan aplikasi Siskeudes karena belum semua desa mengikuti pelatihan pertama, yaitu pelatihan penyusunan APBDes. Format pelatihan dilaksanakan di bulan April sementara penetapan Raperdes (Rancangan Peraturan desa) di bulan Oktober.

Berdasarkan uraian di atas, dapat ditemukan sebagai berikut:

1. Program Pengembangan kapasitas baik melalui sosialisasi, pelatihan dan bimbingan teknis terutama yang dilakukan dengan inisiatif desa melalui asosiasi Dinas Pemberdayaan Masyarakat dan Desa belum terdokumentasi dengan baik, sehingga pihak Pengembangan Aparatur Desa PMD tidak memiliki data untuk pelatihan-pelatihan yang dilakukan desa. Pelatihan juga belum terintegrasi. Selama ini pelatihan dilakukan terpisah-pisah sesuai Dinas yang berkaitan, sehingga perlu pelatihan terintegrasi.

2. Program Pengembangan kapasitas SDAP yang pernah dilakukan meliputi: sosialisasi, pelatihan dan bimbingan teknis penyusunan perdes tentang kewenangan desa, peningkatan kapasitas Tim Pengelola Kegiatan (TPK) desa, penyusunan RKP desa, penyusunan APBDes, pembuatan laporan pertanggungjawaban APBDes, aplikasi Siskeudes, penganggaran desa, pengelolaan keuangan dan administrasi desa, sosialisasi tupoksi Badan Permusyawaratan Desa (BPD) dan sosialisasi pengangkatan dan pemberhentian perangkat desa/lembaga kemasyarakatan desa, misalnya kepala dusun atau RT, serta pelatihan untuk BUMDes.

\section{KESIMPULAN}

Berdasarkan analisis data lapangan, dapat disimpulkan beberapa hal sebagai berikut: sebagian kecil $(5,11 \%)$ desa dan kelurahan di Kalimantan Timur yang belum mempunyai kepala desa disebabkan oleh masa jabatan kepala desa sebelumnya yang telah habis dan belum dilakukkannya pemilihan kepala desa yang baru. Sebanyak 101 desa $(9,73 \%)$ belum mempunyai sekretaris desa. Sumberdaya Aparatur Desa di wilayah perdesaan di Kalimantan Timur secara umum mempunyai karakteristik: mayoritas berumur 35 tahun-54 tahun, mayoritas berpendidikan SMA $(54,42 \%)$ dan Diploma (26,40\%). Perempuan telah diberikan kesempatan untuk menjadi pemimpin dan pengurus desa. Beberapa wilayah dipimpin oleh kepala desa perempuan $(5,18 \%)$ dan sekretaris desa perempuan $(17,18 \%)$. Sumberdaya aparatur desa di wilayah perdesaan di Kalimantan Timur secara umum berada dalam umur produktif, pengalaman yang memadai terutama berkaitan dengan 
pengetahuan kearifan lokal. Namun demikian, mempunyai keterbatasan terhadap kapasitas manajerial, kapasitas kewirausahaan serta kapasitas berfikir konseptual.

Belum optimalnya kapasitas sumberdaya aparatur desa di wilayah perdesaan di Kalimantan Timur diantaranya terlihat dalam aktivitas perencanaan dan penganggaran desa, keuangan desa, penyusunan kebijakan desa, dan manajemen pelayanan desa. Dalam perencanaan dan penganggaran, banyak desa mempunyai hambatan dalam memetakan potensi desa, memahami isuisu yang berkembang di masyarakat desa, kemampuan menguasai berbagai kebijakan pemerintah daerah, kemampuan membangun persepsi yang sama antara pemerintah desa dan BPD, serta dalam penyusunan dokumen-dokumen perencanaan. Kapasitas manajemen keuangan, SDAP desa terbatas dalam kapasitas manajemen operasional, pembiayaan dan investasi. Banyak desa belum dapat menentukan skala prioritas serta distribusi sumber daya dengan baik. Dalam pelaksanaan dan penatausahaan keuangan desa, administrasi desa belum terselenggara dengan baik, pelaporan dan pertanggungjawaban keuangan desa juga belum dilakukan dengan baik. Pengelolaan potensi desa untuk menambah pendapatan desa dapat dikatakan juga masih belum optimal. Badan Usaha Milik Desa yang diharapkan bisa meningkatkan pendapatan asli desa cenderung belum terkelola dengan baik. Akhirnya, dari sisi penerimaan keuangan desa masih sangat bergantung dari transfer pemerintah yang ada di atasnya.

Dalam hal kebijakan desa, jumlah kebijakan desa yang disusun masih minim. Sosialisasi, pelatihan dan simulasi tentang penyusunan kebijakan desa yang diselenggarakan oleh Badan Pemberdayaan Masyarakat dan Pemerintahan Desa Propinsi dan Badan Pemberdayaan Masyarakat dan Pemerintahan Desa Kabupaten masih sangat terbatas, karena keterbatasan sumber-sumber daya yang dimiliki oleh institusi tersebut.

Dalam hal manajemen pelayanan desa, pemerintahan desa dalam pelayanan publik menghadapi keterbatasan kapasitas manajemen-administratif. Kurangnya sarana dan prasarana perkantoran menjadi penghambat dalam menunjang pelaksanaan pelayanan administrasi di desa. Kondisi geografis wilayah perdesaan di Kalimantan Timur juga menjadi kendala terhadap aksesibilitas dan kualitas pelayanan terhadap informasi dan pelayanan yang disiapkan pemerintah.

\section{REKOMENDASI}

Strategi yang dapat dikembangkan untuk penguatan SDAP desa dapat direkomendasikan halhal sebagai berikut:

1. Program pengembangan kapasitas SDAP yang dilakukan secara terintegrasi antar lembaga. Pelatihan (bimbingan teknis, pembekalan, penataran, dll) dan non-pelatihan (studi banding, magang) untuk peningkatan kapasitas aparatur desa dalam hal: (1) pemetaan masalah dan potensi desa, (2) metode perencanaan partisipatif, (3) metode pemilihan skala prioritas kegiatan, (4) penyusunan APBDesa, Pengelolaan ADD, dan (5) berkomunikasi/berdiskusi/presentasi. (6) Pengelolaan Kekayaan Desa, Pengelolan BUMDes, (7) pelatihan dan sosialisasi berkesinambungan tentang Penyusunan Kebijakan Desa yang dilaksanakan oleh Badan Pemberdayaan Masyarakat dan Pemerintahan Desa Kabupaten, (8) peningkatan kemampuan aparat desa dalam merumuskan program-program pelayanan, termasuk pengetahuan teknis administratif dan kemampuan memahami petunjuk maupun peraturan undang-undang yang mendukung aparatur desa dalam memberikan pelayanan, selain kemampuan teknis penunjang (seperti dalam mengoperasikan komputer). Kemampuan mengambil keputusan dan kemampuan dalam melakukan kerjasama (LSM, masyarakat, instansi terkait, pemerintah daerah) dalam pelayanan terkait juga perlu ditingkatkan.

2. Program pengembangan kapasitas SDAP tidak hanya aspek teknis, namun juga kapasitas manajemen, kapasitas kewirausahaan dan kapasitas berfikir konseptual. Namun demikian, secara umum SDAP desa mempunyai keterbatasan untuk kapasitas manajemen, kapasitas kewirausahaan dan kapasitas berfikir konseptual, sehingga diperlukan dukungan modulmodul atau aplikasi-aplikasi yang memudahkan SDAP desa, seperti dalam: (1) pemetaan 
masalah dan potensi desa, (2) penyusunan dokumen perencanaan, (3) aplikasi usaha BUM desa (seperti: modul pengelolaan sampah desa, modul mandiri energi, modul pengolahan hasil pertanian, dll.), (4) tersusunnya modul-modul yang berkaitan dengan Perumusan Kebijakan, serta (5) modul program-program pelayanan.

\section{DAFTAR PUSTAKA}

Agus, C., Agus, A., Suhartanto, B. (2015). Pengembangan Sistem Pertanian Siklus-Bio Terpadu untuk Peningkatan Produktivitas Ternak Sapi pada Kelompok Ternak Desa Margoagung, Sayegan, Sleman, Yogyakarta, Indonesian Journal of Community Engagement 1(1), 96-108

Ahmed, A., Hanson, K.T. (2011). Leadership, capacity building and sustainable development in contemporary Africa, World Journal of Entrepreneurship, Management and Sustainable Developmen 7 (2/3/4), $101-111$

Ardani, N.G. (2015). Pengembangan Kompetensi Sumberdaya Aparatur Desa Melalui Strategi Capacity Building: Studi di Kantor Desa Bluru Kidul, Kecamatan Sidoarjo, Kabupaten Sidoarjo, Jurnal Administrasi Publik (JAP) 3(2)

Arsjad, M.F. (2018). Peranan Aparat Desa dalam Pelaksanaan Administrasi Pemerintahan Desa di Desa Karyamukti Kecamatan Mootilango Kabupaten Gorontalo, Gorontalo Journal of Public Administration Studies 1(1), 16-32

Asrori (2014) Kapasitas Perangkat Desa dalam Penyelenggaraan Pemerintahan Desa di Kabupaten Kudus, Jurnal Bina Praja 6(2), 101 - 116

Bappenas. (2016). Kajian Penyusunan Instrumen Evaluasi Pembangunan Perdesaan (Lingkup Desa) Tahun 2016, Kementrian PPM/Bappenas; Direktorat Daerah Tertinggal, Transmigrasi Dan Perdesaan 2016.

Boley, B. \& McGehee, N. (2014). Measuring empowerment: Developing and validating the Resident Empowerment through Tourism Scale (RETS). Tourism Management 45: 8594.

BPS Kalimantan Timur (2014) Statistik Indeks Pembangunan Desa (IPD) Kalimantan Timur Tahun 2014

BPS Kalimantan Timur (2014). Statistik Potensi Desa Kalimantan Timur Tahun 2014

BPS Kalimantan Timur (2018). Statistik Indeks Pembangunan Desa (IPD) Kalimantan Timur Tahun 2018 BPS Kalimantan Timur (2018). Statistik Potensi Desa Kalimantan Timur Tahun 2018

BPS Prov. Kaltim.(2015). Berita Resmi Statistik BPS Provinsi Kalimantan Timur. BRS No. 14/02/64/Th.XVIII, 16 Februari 2015.

Davies, A., (2009). Understanding Local Leadership in Building the Capacity of Rural Communities in Australia, Geographical Research 47(4), 380-389

Denhardt, J.V. dan Denhardt, R.V. (2004). The New Public Service: Serving, not Steering. M.E. Sharpe. New York.

Eka, S., \& Ismiyati, I. (2015). Pengaruh Kepemimpinan, Fasilitas Kerja, dan Motivasi Kerja terhadap Kinerja Perangkat Desa di Kecamatan Mandiraja Kabupaten Banjarnegara. Economic Education Analysis Journal, 4(2)

Guinjoan, E., Badia, A., Tulla, A.F. (2016). The New Paradigm of Rural Development: Theoretical Considerations And Reconceptualization Using The 'Rural Web', Boletín de la Asociación de Geógrafos Españoles 71, 495-500 
Hendri, S., Ardania, N.O.C.A., Rakhmawati, I., Atikah, S. (2016). Pengaruh Sumber Daya Manusia, Sarana dan Prasarana Terhadap Kinerja Pengelolaan Keuangan Desa di Kabupaten Lombok Tengah, Conference on Management and Behavioral Studies Universitas Tarumanagara, Jakarta, 27 Oktober 2016

Herdiana, D. (2019). Pengembangan Konsep Smart Village bagi Desa-Desa di Indonesia, IPTEKKOM 21(1), 1 - 16

Horner, R. (2019). Towards a new paradigm of global development? Beyond the limits of international development, Progress in Human Geography 1-22

Krakowiak-Bal, A., Ziemianczyk, U., Wozniak,A. (2017). Building entrepreneurial capacity in rural areas: The use of AHP analysis for infrastructure evaluation, International Journal of Entrepreneurial Behavior \& Research, https://doi.org/10.1108/IJEBR-07-2017-0223

OECD (2016). A New Rural Development Paradigm for the 21st Century: A Toolkit For Developing Countries. Development Centre Studies, OECD Publishing, Paris. http://dx.doi.org/10.1787/9789264252271-en

Pujiyatno, A. \& Miftahuddin, M.A. (2017). Pengembangan Pertanian Terpadu di Desa Tidu Kecamatan Bukateja Kabupaten Purbalingga, Jurnal Pengabdian Dan Pemberdayaan Masyarakat 1(1), 38-50

Pusut, R., Kimbal, M., Mamentu, M. (2017). Pembangunan Berbasis Pemberdayaan Masyarakat di Desa Pasir Putih Kecamatan Pamona Selatan Kabupaten Poso, Eksekutif: Jurnal Jurusan Ilmu Pemerintahan 2(2), 1-8

Republik Indonesia. (2014). Undang-Undang Nomor 6 Tahun 2014 tentang Desa.Lembaran Negara Republik Indonesia Tahun2014 Nomor7. Jakarta

Romli, O. \& Nurlia, E. (2017). Lemahnya Badan Permusyawaratan Desa (BPD) Dalam Melaksanakan Fungsi Pemerintahan Desa: Studi Desa Tegalwangi Kecamatan Menes Kabupaten Pandeglang, CosmoGov: Jurnal Ilmu Pemerintahan 3(1), 36-54

Sidik, F. (2015). Menggali Potensi Lokal Mewujudkan Kemandirian Desa, Jurnal Kebijakan \& Administrasi Publik 19(2), 115 -131

Steiner, A.A., \& Farmer, J. (2017). Engage, participate, empower: Modelling power transfer in disadvantaged rural communities, Environment and Planning C: Politics and Space 0(0) 1 21

Sulismadi, Wahyudi, Muslimin (2017). Model Penguatan Kapasitas Pemerintah Desa, Aristo: Sosial Politik Humaniora 5(1), 216-258

Suranto (2018). Evaluasi Program Desa Mandiri Informasi Berbasis Aplikasi Android Sistem Informasi Desa (SIFORDES), INFORMASI: Kajian Ilmu Komunikasi 48(1), 48, 1-13

Taufiq, Susilo, B., Hawa, L.C. (2016). Sistem Pengembangan "Desa Mandiri Energi “ (DME) di Desa Sumber Bendo, Saradan, Kabupaten Madiun, Jurnal Keteknikan Pertanian Tropis dan Biosistem 4(2), 128-135

Taufiq,A. \& Purwoko (2013). Identifikasi Desa Mandiri Energi, Jurnal Ilmu Sosial 12(1), 1-13

Vincent, C. \& Stephen, C. (2015). Local Government Capacity Building and Development: Lessons, Challenges and Opportunities. Journal of Political Sciences \& Public Affairs 3, 149

Wiguna,M.D.P.D., Yuniarta, G., A., Prayudi, M.A. (2017). Pengaruh Kualitas Sumber Daya Manusia, Pendidikan dan Pelatihan, Serta Peran Pendamping Desa terhadap Efektivitas 
Pemetaan Sumberdaya Aparatur Desa di Provinsi Kalimantan Timur

Nofiarsyah

Penggunaan Sistem Keuangan Desa (Siskeudes): Studi Pada Desa Penerima Dana Desa Di

Kabupaten Buleleng, e-Journal Universitas Pendidikan Ganesha 8(2), 1-10 